\title{
CHANGES IN A RHODIC HAPLUDOX UNDER NO-TILLAGE AND URBAN WASTE COMPOST IN THE NORTHWEST OF RIO GRANDE DO SUL, BRAZIL ${ }^{(1)}$
}

\author{
Moacir Tuzzin de Moraes ${ }^{(2)}$,Vanderlei Rodrigues da Silva ${ }^{(3)}$, Maurício Roberto Cherubin $^{(4)}$, \\ Reimar Carlesso $^{(5)}$, Henrique Debiasi $^{(6)}$ \& Renato Levien $^{(7)}$
}

\begin{abstract}
SUMMARY
The use of urban waste compost as nutrient source in agriculture has been a subject of investigation in Brazil and elsewhere, although the effects on soil physical and chemical properties and processes are still poorly known. The aim of this study was to evaluate the effect of application of urban waste compost and mineral fertilizer on soil aggregate stability and organic carbon and total nitrogen content of a Rhodic Hapludox under no-tillage in the northwestern region of Rio Grande do Sul, Brazil, in the 2009/2010 and 2010/2011 growing seasons. The experiment was arranged in a $2 \times 6$ (seasons and fertilization) factorial in a randomized complete block design with four replications. The factor time consisted of two growing seasons (sunflower in 2009/10 and maize in 2010/11) and the factor fertilization of five rates of urban waste compost $\left(0,25,50,75\right.$ and $\left.100 \mathrm{~m}^{3} \mathrm{ha}^{-1}\right)$, and mineral fertilizer. Soil samples were collected from the 0.0-0.10 $\mathrm{m}$ layer to determine aggregate stability (mean weight and geometric diameter), soil organic carbon (SOC) and total nitrogen (TN). Rates of up to $75 \mathrm{~m}^{3} \mathrm{ha}^{-1}$ of urban waste compost, after two years of application to no-tillage maize and sunflower, improved aggregation compared to mineral fertilization in a Rhodic Hapludox. After the second crop, the SOC and TN contents increased linearly with the levels of urban waste compost.
\end{abstract}

Index terms: soil organic carbon, aggregate stability, total nitrogen, soil structure, organic manure.

(1) Received for publication on September 4, 2013 and approved on May 16, 2014.

(2) Doctorate's student, Graduate Program on Soil Science, Federal University of Rio Grande do Sul - UFRGS. Av. Bento Gonçalves, 7712, Building 41506. CEP 91540-000 Porto Alegre (RS), Brazil. E-mail: moacir.tuzzin@gmail.com

(3) Professor, Department of Environment and Agronomy Science, UFSM. Campus Frederico Westphalen. Linha Sete de Setembro, s/n. Rod. BR 386, km 40. CEP 98400-000 Frederico Westphalen (RS), Brazil. E-mail: vanderlei@ufsm.br

(4) Doctorate's student, Graduate Program on Soil and Plant Nutrition, Luiz de Queiroz College of Agriculture - University of São Paulo - ESALQ/USP. Av. Pádua Dias, 11, Postal Box 9. CEP 13418-900 Piracicaba (SP), Brazil. E-mail: cherubin@usp.br

(5) Professor, Department of Rural Engineering, UFSM, Rural Sciences Center, Campus UFSM. Street Q, 68, Camobi. CEP 97105-900 Santa Maria (RS), Brazil. E-mail: carlesso@ccr.ufsm.br

(6) Researcher, Embrapa Soja. Rod. Carlos João Strass, Distrito de Warta. Postal Box 231. CEP 86001-970 Londrina (PR), Brazil. E-mail: henrique.debiasi@embrapa.br

(7) Professor Associate, Department of Soil Science, UFRGS. E-mail: renatole@gmail.com 


\title{
RESUMO: ALTERAÇÕES EM LATOSSOLO MANEJADO EM SISTEMA PLANTIO DIRETO COM ADIÇÃO DE COMPOSTO DE LIXO URBANO, NO NOROESTE DO RIO GRANDE DO SUL
}

\begin{abstract}
A utilização de composto de lixo urbano como fonte de nutrientes para a agricultura vem sendo investigada; entretanto, as alterações físicas do solo ainda são pouco conhecidas. Objetivouse avaliar a influência do uso de composto de lixo urbano e da adubação mineral na estabilidade de agregados e nos teores de carbono orgânico e nitrogênio total de um Latossolo Vermelho, em sistema plantio direto na região noroeste do Rio Grande do Sul. Utilizou-se o delineamento de blocos ao acaso, em esquema fatorial $6 \times 2$ (adubação e épocas), com quatro repetições. O fator épocas de avaliação constituiu-se dos anos agrícolas de 2009/10 (girassol) e 2010/11 (milho). O fator adubação foi composto por cinco doses de composto de lixo urbano $\left(0,25,50,75\right.$ e $\left.100 \mathrm{~m}^{3} \mathrm{ha}^{-1}\right)$, além de um tratamento adicional com fertilização mineral. Na camada de 0,0-0,10 $\mathrm{m}$, foram determinados a estabilidade de agregados (diâmetro médio geométrico e ponderado), os teores de carbono orgânico (CO) e o nitrogênio total (NT). A utilização de doses crescentes de composto de lixo urbano favoreceu melhorias na agregação do solo, em relação à fertilização mineral. A utilização de até $75 \mathrm{~m}^{3} \mathrm{ha}^{-1}$ de composto de lixo urbano, após dois anos de aplicações em cultivos agrícolas com milho $e$ girassol em um Latossolo Vermelho, sob sistema plantio direto, promoveu melhorias na agregação do solo, quando comparada à fertilização mineral. O teor de CO e o de NT, após o segundo cultivo, apresentaram incrementos lineares, em relação às doses de composto de lixo urbano.
\end{abstract}

Termos de indexação: carbono orgânico, estabilidade de agregados, estrutura do solo, resíduo orgânico.

\section{INTRODUCTION}

The growth of large urban centers has led to uncontrolled increases in the generation and disposal of organic wastes, accelerating the degradation rate of natural resources. Thus, finding viable alternatives for a more adequate waste disposal, with a view to reducing environmental impacts, is understood as one of the greatest challenges the society is facing since the beginning of the 21st century (Abreu Junior et al., 2005; Calderan et al., 2012). In this context, studies investigating the potential use of urban wastes for crop production have become increasingly important (Citak \& Sonmez, 2011; Moraes et al., 2012; Strojaki et al., 2013).

The use of urban waste compost in agriculture allows the cycling of organic matter and nutrients (Melo et al., 2011), and thus helps to maintain or restore soil chemical, physical and biological properties (Kray et al., 2011; Krob et al., 2011). In this sense, several studies have addressed the changes in soil chemical properties and plant nutrition induced by the application of urban waste compost (Sampaio et al., 2010; Krob et al., 2011; Lima et al., 2011). Strojaki et al. (2013) found that successive applications of urban waste compost to an Oxisol in the northwestern region of Rio Grande do Sul led to a decrease in potential acidity and increases in soil cation exchange capacity, base saturation, and exchangeable calcium and magnesium. These authors claimed that urban waste compost as potential manure could replace mineral fertilizers in field cultivation of maize and sunflower. However, studies on the effects of this compost as soil conditioner are scarce in Brazil (Costa et al., 2008; Sampaio et al., 2012).

Among the soil physical properties, soil aggregation is an important indicator of soil quality (Vezzani \& Mielniczuk, 2009). Soil aggregation can be defined as the bonding of the primary particles to soil structural units (aggregates), and its stability is characterized by its resistance to degradation by mechanical action, particularly in water (Six et al., 2004). The flocculation of soil primary particles and organo-mineral complexes and cementing of the flocs are favored by clay domains, humic substances, roots, fungal hyphae, and easily decomposed organic compounds, which are vital components in soil aggregate formation and stability (Tisdall \& Oades, 1982).

Thus, the addition of organic materials to the soil, such as urban waste compost in different decomposition stages, seems to contribute to high levels of soil organic matter (Mantovani et al., 2006) and enhance the cementation and stabilization processes of soil aggregation. The evolution of the soil aggregation state improves the soil structure, which can consequently increase soil porosity, aeration, infiltration and erosion resistance (Matos et al., 2008; Vezzani \& Mielniczuk, 2009; Bonini \& Alves, 2011; Santi et al., 2012). The increase in the proportion of macroaggregates and the high organic carbon contents can characterize an improved soil structure, because the soil properties reach levels at which soil functions are fully operational (Vezzani \& Mielniczuk, 2009). Thus, the correlation between the increased and/or maintained carbon stocks and soil structural improvements (Rozane et al., 2010; Conceição et al., 2013) calls for studies on strategies for the use of 
organic manure, which could supplement or even replace, partially or completely, chemical fertilizers to improve crop yields. Given the above, the aim of this study was to evaluate changes in aggregate stability, organic carbon and total nitrogen of a Rhodic Hapludox under no-tillage and application of different urban waste compost rates and mineral fertilizer in the northwestern region of Rio Grande do Sul, Brazil.

\section{MATERIAL AND METHODS}

The study was carried out in the 2009/10 and 2010/ 11 growing seasons at the Experimental Station of the Federal University of Santa Maria, Frederico Westphalen Campus, Rio Grande do Sul, Brazil (latitude $27^{\circ} 39^{\prime} \mathrm{S}$, longitude $53^{\circ} 42^{\prime} \mathrm{W}, 490 \mathrm{~m}$ asl). According to the classification of Maluf (2000), the climate is subtropical, with wet spring conditions, a mean annual temperature of $18.1{ }^{\circ} \mathrm{C}$ and rainfall of $1,919 \mathrm{~mm} \mathrm{yr}^{-1}$.

The soil of the experimental area was classified as Latossolo Vermelho aluminoférrico típico (Santos et al., 2013), equivalent to the Rhodic Hapludox of the USDA soil classification (Soil Survey Staff, 2010), clayey texture (650 $\mathrm{g} \mathrm{kg}^{-1}$ clay). The soil management used in the area was no-tillage (NT) and crop rotation since 2000, with crops including soybean (Glycine max), wheat (Triticum aestivum), maize (Zea mays), oat (Avena strigosa), and canola (Brassica napus). The chemical properties of the soil surface layer (0.0-0.10 m) before the experiment are shown in table 1.

The experiment was arranged in a $6 \times 2$ factorial (fertilization $\mathrm{x}$ seasons), randomized complete block design with four replications. The time factor consisted of the growing seasons 2009/10 and 2010/11 and the fertilization factor of rates $(0 ; 25 ; 50 ; 75$ and $100 \mathrm{~m}^{3} \mathrm{ha}^{-1}$ ) of urban waste compost (UWC), and a mineral fertilizer (nitrogen, phosphorus and potassium - NPK) rates. The amount of mineral fertilizer applied in the additional treatment was determined according to the recommended amount for sunflower, oat and maize by the Commission of Chemistry and Soil Fertility of the Rio Grande do Sul and Catarina States, Bazil (CQFS-RS/SC, 2004).
The UWC was obtained from the separation and composting of the organic fractions of urban waste residues at a solid waste recycling unit, known as Intermunicipal Consortium for Solid Waste Management (CIGRES), located in Seberi, State of Rio Grande do Sul, Brazil (latitude $27^{\circ} 15^{\prime}$ S; longitude $\left.53^{\circ} 15^{\prime} \mathrm{W}\right)$. The CIGRES serves 30 municipalities in the Northwest of Rio Grande do Sul, including the regions of Médio Alto Uruguai, Zona da Produção and Celeiro. This consortium receives $1380 \mathrm{Mg}$ of municipal solid waste monthly, of which $59.5 \%$ is organic material (Calderan, 2013). The physical and chemical characteristics of the UWC are shown in table 2.

The crop rotation system consisted of sunflower in 2009/10, oat in 2010 and maize in the 2010/11 growing seasons. Both maize and sunflower were sown with a hand-planter. The respective UWC rates were also applied by hand to the soil surface before planting. The crops were planted as follows: sunflower on July 27, 2009, oat on May 15, 2010 and maize on September 10, 2010. For the treatment with mineral fertilizer, $10 \mathrm{~kg} \mathrm{ha}^{-1} \mathrm{~N}$ and $30 \mathrm{~kg} \mathrm{ha}^{-1} \mathrm{P}_{2} \mathrm{O}_{5}$ was applied on the surface at sunflower planting, and then $50 \mathrm{~kg} \mathrm{ha}^{-1} \mathrm{~N}$ as topdressing, for an expected grain yield of 2.0 $\mathrm{Mg} \mathrm{ha}^{-1}$. For maize, $20 \mathrm{~kg} \mathrm{ha}^{-1} \mathrm{~N}, 45 \mathrm{~kg} \mathrm{ha}^{-1} \mathrm{P}_{2} \mathrm{O}_{5}$ and $30 \mathrm{~kg} \mathrm{ha}^{-1} \mathrm{~K}_{2} \mathrm{O}$ were applied at sowing and $70 \mathrm{~kg} \mathrm{ha}^{-1} \mathrm{~N}$ as top dressing for an expected grain yield of 8.0 $\mathrm{Mg} \mathrm{ha}{ }^{-1}$. For oat, used as cover crop, fertilization consisted of $31 \mathrm{~kg} \mathrm{ha}^{-1} \mathrm{P}, 12 \mathrm{~kg} \mathrm{ha}^{-1} \mathrm{~K}$ and $56 \mathrm{~kg} \mathrm{ha}^{-1} \mathrm{~N}$, for an expected production of $5 \mathrm{Mg}^{-1} \mathrm{ha}^{-1}$ dry mass yield. The nutrient sources of the chemical fertilizers were urea, triple superphosphate and potassium chloride for N, P and K, respectively. Table 3 shows the total amounts of nutrients used for the three crops.

Soil sampling was performed in the $0.0-0.10 \mathrm{~m}$ layer at sunflower harvest in 2009/10 and maize in 2010/11. For each evaluation, two soil samples were collected, that is, two soil monoliths per plot (depth $0.10 \mathrm{~m}$, length $0.20 \mathrm{~m}$, width $0.05 \mathrm{~m}$ ) for the determination of soil aggregate stability, organic carbon and total nitrogen. The samples were prepared by hand breaking of clods, applying pressure but avoiding compaction, to determine the shear soil strength of the aggregates. Soil aggregates with diameters between 4.76 to $8.00 \mathrm{~mm}$ were used.

The aggregate stability was determined using the standard wet method (Kemper \& Chepil, 1965), with three sub-samples of $25 \mathrm{~g}$, in which two (duplicate) of

Table 1. Chemical properties of the soil surface layer $(0.0-0.10 \mathrm{~m})$ before the experiment

\begin{tabular}{|c|c|c|c|c|c|c|c|c|c|c|c|c|c|}
\hline \multicolumn{2}{|c|}{$\mathbf{p H}$} & \multirow{2}{*}{$\mathrm{Ca}$} & \multirow{2}{*}{ Mg } & \multirow{2}{*}{ Al } & \multirow{2}{*}{$\mathrm{CEC}_{\mathrm{pH} 7}^{(2)}$} & \multirow{2}{*}{$\mathbf{P}$} & \multirow{2}{*}{$\mathbf{K}$} & \multirow{2}{*}{$\mathrm{Cu}$} & \multirow{2}{*}{$\mathrm{Zn}$} & \multirow{2}{*}{$\mathrm{S}$} & \multirow{2}{*}{$\mathrm{V}^{(3)}$} & \multirow{2}{*}{$\operatorname{SOM}^{(4)}$} & \multirow{2}{*}{ Clay } \\
\hline $\mathrm{H}_{2} \mathrm{O}$ & $\operatorname{SMP}^{(1)}$ & & & & & & & & & & & & \\
\hline & & 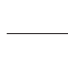 & $\mathrm{cmo}$ & $m^{-3}$ & 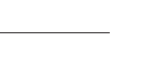 & 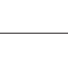 & $\mathrm{r}$ & $\mathrm{dm}^{-3}$ & 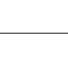 & - & $\%$ & $-\mathrm{g} \mathrm{k}$ & $g^{-1}$ \\
\hline 5.1 & 6.2 & 5.5 & 1.6 & 0.2 & 11.1 & 7.6 & 280.0 & 5.8 & 1.8 & 11.1 & 69 & 32 & 650 \\
\hline
\end{tabular}


Table 2. Physical and chemical characteristics of the urban waste compost used in the study

\begin{tabular}{|c|c|c|c|c|c|c|c|c|}
\hline $\mathrm{pH}\left(\mathrm{H}_{2} \mathrm{O}\right)$ & $\mathbf{P}$ & $\mathbf{K}$ & $\mathrm{S}$ & $\mathrm{Zn}$ & $\mathrm{Cu}$ & $\mathrm{Ca}$ & Organic matter & $\mathrm{BD}^{(1)}$ \\
\hline & & 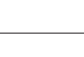 & $\operatorname{gg} \mathrm{dn}$ & & $\ldots$ & $\mathrm{cmol}_{\mathrm{c}} \mathrm{dm}^{-3}$ & $\mathrm{~g} \mathrm{~kg}^{-1}$ & $\mathrm{~kg} \mathrm{dm}^{-3}$ \\
\hline 7.6 & 117.4 & 130.0 & 5.4 & 0.5 & 0.3 & 30.1 & 102.0 & 0.40 \\
\hline
\end{tabular}

(1) BD: bulk density of urban waste compost.

Table 3. Annual nutrient input applied with urban waste compost and mineral fertilizer

\begin{tabular}{crcr}
\hline UWC rate & N & P & K \\
\hline $\mathrm{m}^{3}$ ha $^{-1}$ & \multicolumn{3}{c}{ Urban waste compost $^{(1)}$} \\
& 0 & 0 & 0 \\
0 & 97 & 50 & 44 \\
25 & 194 & 100 & 88 \\
50 & 291 & 150 & 132 \\
75 & 388 & 200 & 176 \\
100 & & Mineral fertilizer & \\
Crop & 72 & 41 & 34 \\
Sunflower & 83 & 77 & 52 \\
Oat & 56 & 31 & 12 \\
Maize & & & \\
\hline
\end{tabular}

(1) Rates of urban waste compost applied at sowing of each crop (sunflower, oat and maize); UWC: urban waste compost.

the sub-samples were used for aggregate stability and the other third sub-sample for soil moisture content. The aggregates were moistened slowly by capillarity and after $10 \mathrm{~min}$, subjected to aggregate stability analysis in a vertical oscillator (Yoder, model MA-148 unit), at a speed of 30 oscillations per min for $10 \mathrm{~min}$. The vertical oscillator consists of set of four sieves (mesh size $4.76 \mathrm{~mm}, 2.0 \mathrm{~mm}, 1.00 \mathrm{~mm}$, and $0.21 \mathrm{~mm}$ ). The aggregates were then separated into the following classes: $8.00-4.76 \mathrm{~mm}$; 4.76-2.00 mm; $2.00-1.00 \mathrm{~mm}$; $1.00-0.21 \mathrm{~mm}$ and $<0.21 \mathrm{~mm}$. The aggregates retained on each sieve were dried at $\pm 105^{\circ} \mathrm{C}$ for $48 \mathrm{~h}$, and the dry mass was determined.

After the determination of the aggregate dry mass in the different classes, the aggregates were chemically dispersed (NaOH $2 \%$ for $30 \mathrm{~s}$ ) for the quantification of the masses $\left(105^{\circ} \mathrm{C}\right.$ for $\left.48 \mathrm{~h}\right)$ of inert materials ((i.e., sand graved and large particles of organic material of the UWC). The inert materials were substracted of the aggregates to each aggregate size fraction. From the mass of soil retained on each sieve, the geometric mean diameter (GMD) and mean weight diameter (MWD) of soil aggregates were calculated according to the method described by Kemper \& Chepil, (1965). Soil organic carbon and total nitrogen contents were determined by dry combustion in an elemental autoanalyzer, by the method proposed by Rheinheimer et al. (2008). The carbon/nitrogen (C:N) ratio of soil samples was calculated.
Data were subjected to analysis of variance (ANOVA) by F-test $(\mathrm{p}<0.05)$. Quantitative treatments (UWC rates) with significant effects were subjected to polynomial regression by the F-test $(p<0.05)$. Orthogonal analysis $(p<0.05)$ was performed to compare UWC rates with mineral fertilization. Statistical analyses were performed using the package Statistical Analysis System version 8.0 (SAS Institute Inc.).

\section{RESULTS AND DISCUSSION}

Analysis of variance (ANOVA) revealed significant effects of the interaction between the factors, fertilization (UWC rates and mineral fertilizer) and crop growing season (2009/10 and 2010/11) on all properties evaluated, with the exception of the $\mathrm{C}: \mathrm{N}$ ratio (Table 4).

In the first year of cultivation (2009/10), the rate of $100 \mathrm{~m}^{3} \mathrm{ha}^{-1}$ of UWC led to significant increases in the values of GMD and MWD compared to mineral fertilization (Table 5). This treatment decreased the percentage of retained aggregates of the classes below $1.00 \mathrm{~mm}$ compared to mineral fertilization, indicating improvements in soil aggregation, since there was less dispersion of smaller classes $(<1 \mathrm{~mm})$ of soil aggregates. Aggregation and soil aggregate stability depend on some soil physical and chemical properties, especially organic matter, clay minerals and $\mathrm{Fe}$ and Al oxides (Tisdall \& Oades, 1982; Azevedo \& Bonumá, 2004; Six et al., 2004; Reichert et al., 2009). High GMD and MWD values (above $5 \mathrm{~mm}$ ) were observed in the control treatment (without UWC application), which is associated with the characteristic large amount of $\mathrm{Fe}$ and $\mathrm{Al}$ oxide and $\mathrm{Al}$ in Oxisols (Azevedo $\&$ Bonumá, 2004). Furthermore, the results can be attributed to the fact that all treatments were notillage systems, which promoted an increase in soil aggregate stability.

After the second year of cultivation (2010/11), UWC rates from 25 to $75 \mathrm{~m}^{3} \mathrm{ha}^{-1}$ increased both GMD and MWD in comparison with mineral fertilization, indicating improved soil aggregate stability (Table 5). However, the use of $100 \mathrm{~m}^{3} \mathrm{ha}^{-1}$ in the 2010/11 growing season induced no differences in GMD and MWD compared to mineral fertilizer, which can be associated, partly, to the predominance of the dispersing effect of the chemical elements (Medeiros 
Table 4. Analysis of variance of the physical and chemical properties of the Rhodic Hapludox treated with different rates of urban waste compost and mineral fertilizer in two crop growing seasons

\begin{tabular}{lcccccccccc}
\hline \multirow{2}{*}{ Source of variation } & \multicolumn{10}{c}{ Cause of variation } \\
\cline { 2 - 11 } & GMD & MWD & $\mathbf{8 . 0 0 - 4 . 7 6}$ & $\mathbf{4 . 7 6 - 2 . 0 0}$ & $\mathbf{2 . 0 0 - 1 . 0 0}$ & $\mathbf{1 . 0 0 - 0 . 2 1}$ & $<\mathbf{0 . 2 1}$ & SOC & TN & C:N ratio \\
\hline Fertilization & $*$ & $*$ & $*$ & $*$ & $*$ & $*$ & $*$ & $*$ & $*$ & $\mathrm{~ns}$ \\
Year & $\mathrm{ns}$ & $*$ & $*$ & $*$ & $*$ & $*$ & $*$ & $*$ & $*$ & $\mathrm{~ns}$ \\
Fert. vs year & $*$ & $*$ & $*$ & $*$ & $*$ & $*$ & $*$ & $*$ & $*$ & $\mathrm{~ns}$ \\
CV (\%) & 6.81 & 3.15 & 4.77 & 40.19 & 48.12 & 42.44 & 42.76 & 7.93 & 8.09 & 2.15 \\
\hline
\end{tabular}

* significant by the F-test ( $<<.05)$; ns: not significant. Fert: fertilization; GMD: geometric mean diameter; DMP: mean weight diameter. SOC: soil organic carbon; TN: total nitrogen; CV: coefficient of variation.

Table 5. Orthogonal contrasts between rates of urban waste compost (UWC) and mineral fertilizer applied to a Rhodic Hapludox

\begin{tabular}{|c|c|c|c|c|c|c|}
\hline \multirow{2}{*}{ Variable } & \multicolumn{5}{|c|}{ UWC rate, $\mathrm{m}^{3} \mathrm{ha}^{-1}$} & \multirow{2}{*}{ Mineral fertilize } \\
\hline & $\mathbf{0}$ & 25 & 50 & 75 & 100 & \\
\hline \multicolumn{7}{|c|}{ 2009/10 growing season } \\
\hline Geometric mean diameter, $\mathrm{mm}$ & $5.04^{\mathrm{ns}}$ & $5.25^{\mathrm{ns}}$ & $5.08^{\text {ns }}$ & $4.97^{\mathrm{ns}}$ & $5.71^{*}$ & 5.17 \\
\hline Mean weight diameter, mm & $5.82^{\mathrm{ns}}$ & $5.90^{\mathrm{ns}}$ & $5.81^{\mathrm{ns}}$ & $5.78^{\mathrm{ns}}$ & $6.09^{*}$ & 5.86 \\
\hline Aggregate $8.00-4.76 \mathrm{~mm}, \%$ & $88.02^{\mathrm{ns}}$ & $89.84^{\mathrm{ns}}$ & $87.62^{\mathrm{ns}}$ & $87.26^{\mathrm{ns}}$ & $93.54^{\mathrm{ns}}$ & 88.67 \\
\hline Aggregate $4.76-2.00 \mathrm{~mm}, \%$ & $5.05^{\mathrm{ns}}$ & $3.82^{\mathrm{ns}}$ & $5.23^{\mathrm{ns}}$ & $4.65^{\mathrm{ns}}$ & $3.10^{\mathrm{ns}}$ & 4.70 \\
\hline Aggregate $2.00-1.00 \mathrm{~mm}, \%$ & $1.65^{\mathrm{ns}}$ & $2.19^{\mathrm{ns}}$ & $2.19^{\mathrm{ns}}$ & $2.83^{\mathrm{ns}}$ & $1.18^{\mathrm{ns}}$ & 2.20 \\
\hline Aggregate $1.00-0.21 \mathrm{~mm}, \%$ & $1.93^{\mathrm{ns}}$ & $1.60^{\mathrm{ns}}$ & $2.10^{\mathrm{ns}}$ & $2.07^{\mathrm{ns}}$ & $0.83^{*}$ & 1.73 \\
\hline Aggregate $<0.21 \mathrm{~mm}, \%$ & $3.32^{\mathrm{ns}}$ & $2.53^{\mathrm{ns}}$ & $2.85^{\mathrm{ns}}$ & $3.15^{\mathrm{ns}}$ & $1.32^{*}$ & 2.69 \\
\hline Soil organic carbon, $\mathrm{g} \mathrm{kg}^{-1}$ & $19.00^{\mathrm{ns}}$ & $19.80^{\mathrm{ns}}$ & $19.90^{\mathrm{ns}}$ & $19.10^{\mathrm{ns}}$ & $20.80^{\mathrm{ns}}$ & 20.60 \\
\hline Total nitrogen, $\mathrm{g} \mathrm{kg}^{-1}$ & $1.70^{\mathrm{ns}}$ & $1.80^{\mathrm{ns}}$ & $1.80^{\mathrm{ns}}$ & $1.80^{\mathrm{ns}}$ & $1.90^{\text {ns }}$ & 1.90 \\
\hline $\mathrm{C} / \mathrm{N}$ ratio & $10.64^{\mathrm{ns}}$ & $11.05^{\mathrm{ns}}$ & $10.91^{\mathrm{ns}}$ & $10.73^{\mathrm{ns}}$ & $10.71^{\mathrm{ns}}$ & 10.71 \\
\hline \multicolumn{7}{|c|}{ 2010/11 growing season } \\
\hline Geometric mean diameter, $\mathrm{mm}$ & $5.01^{\mathrm{ns}}$ & $5.47^{*}$ & $5.29 *$ & $5.37 *$ & $4.98^{\mathrm{ns}}$ & 4.70 \\
\hline Mean weight diameter, mm & $5.75^{\text {ns }}$ & $5.96^{*}$ & $5.86^{*}$ & $5.90^{*}$ & $5.72^{\text {ns }}$ & 5.53 \\
\hline Aggregate $8.00-4.76 \mathrm{~mm}, \%$ & $86.39^{\mathrm{ns}}$ & $90.72^{*}$ & $88.68^{*}$ & $89.44^{*}$ & $85.71^{\mathrm{ns}}$ & 81.08 \\
\hline Aggregate $4.76-2.00 \mathrm{~mm}, \%$ & $5.29^{*}$ & $4.07^{*}$ & $4.78^{*}$ & $4.57^{*}$ & $5.99^{\text {ns }}$ & 8.11 \\
\hline Aggregate $2.00-1.00 \mathrm{~mm}, \%$ & $2.70^{\mathrm{ns}}$ & $1.70^{*}$ & $2.40^{*}$ & $2.12^{*}$ & $2.61^{\mathrm{ns}}$ & 3.94 \\
\hline Aggregate $1.00-0.21 \mathrm{~mm}, \%$ & $3.52^{\mathrm{ns}}$ & $2.22^{*}$ & $2.72^{*}$ & $2.56^{*}$ & $3.41^{\mathrm{ns}}$ & 4.65 \\
\hline Aggregate $<0.21 \mathrm{~mm}, \%$ & $2.09^{\text {ns }}$ & $1.28^{\mathrm{ns}}$ & $1.40^{\mathrm{ns}}$ & $1.29^{\text {ns }}$ & $2.26^{\mathrm{ns}}$ & 2.20 \\
\hline Soil organic carbon, $\mathrm{g} \mathrm{kg}^{-1}$ & $22.30^{\mathrm{ns}}$ & $25.00^{\mathrm{ns}}$ & $24.80^{\mathrm{ns}}$ & $26.90^{\mathrm{ns}}$ & $30.40^{*}$ & 23.40 \\
\hline Total nitrogen, $\mathrm{g} \mathrm{kg}^{-1}$ & $2.10^{\mathrm{ns}}$ & $2.30^{\mathrm{ns}}$ & $2.30^{\mathrm{ns}}$ & $2.50^{\mathrm{ns}}$ & $2.90^{*}$ & 2.20 \\
\hline $\mathrm{C} / \mathrm{N}$ ratio & $10.65^{\text {ns }}$ & $10.81^{\mathrm{ns}}$ & $10.81^{\mathrm{ns}}$ & $10.99^{\mathrm{ns}}$ & $10.69^{\mathrm{ns}}$ & 10.76 \\
\hline
\end{tabular}

* significant by orthogonal contrast test $(\mathrm{p}<0.05)$; ${ }^{\text {ns }}$ : not significant.

et al., 2009) or organic acids (Oades, 1984) on the aggregating effects observed in the second year. Thus, the continuous use of mineral fertilizers over time can reduce soil aggregate stability (Matos et al., 2008).

The effects of UWC rates on GMD and MWD varied with the year of assessment (Figure 1). The results of GMD and MWD observed for the 2009/10 growing season increased linearly with increasing UWC rates.

In the 2010/11 growing season, the response of GMD and MWD in relation to the different UWC rates was positive quadratic (Figure 1). Also in this growing season, the point with maximum technical efficiency for GMD (5.44 mm) was obtained with a UWC rate of $42.5 \mathrm{~m}^{3} \mathrm{ha}^{-1}$. However, the point of maximum technical efficiency for the MWD (5.97 $\mathrm{mm}$ ) was obtained using $50.6 \mathrm{~m}^{3} \mathrm{ha}^{-1}$ of UWC. Thus, there were significant differences in the results of soil aggregate stability as a function of the amount of UWC applied and the growing seasons, and in relation to the 2010/ 11 growing season, there was reduction in the GMD and MWD values from rates of UWC close to $50 \mathrm{~m}^{3} \mathrm{ha}^{-1}$. The reduction of soil aggregate stability in the 2010/ 11 growing season at UWC rates of $50 \mathrm{~m}^{3} \mathrm{ha}^{-1}$ may be due to the increased dispersion caused by the compost, as similarly observed by Medeiros et al. (2009) 


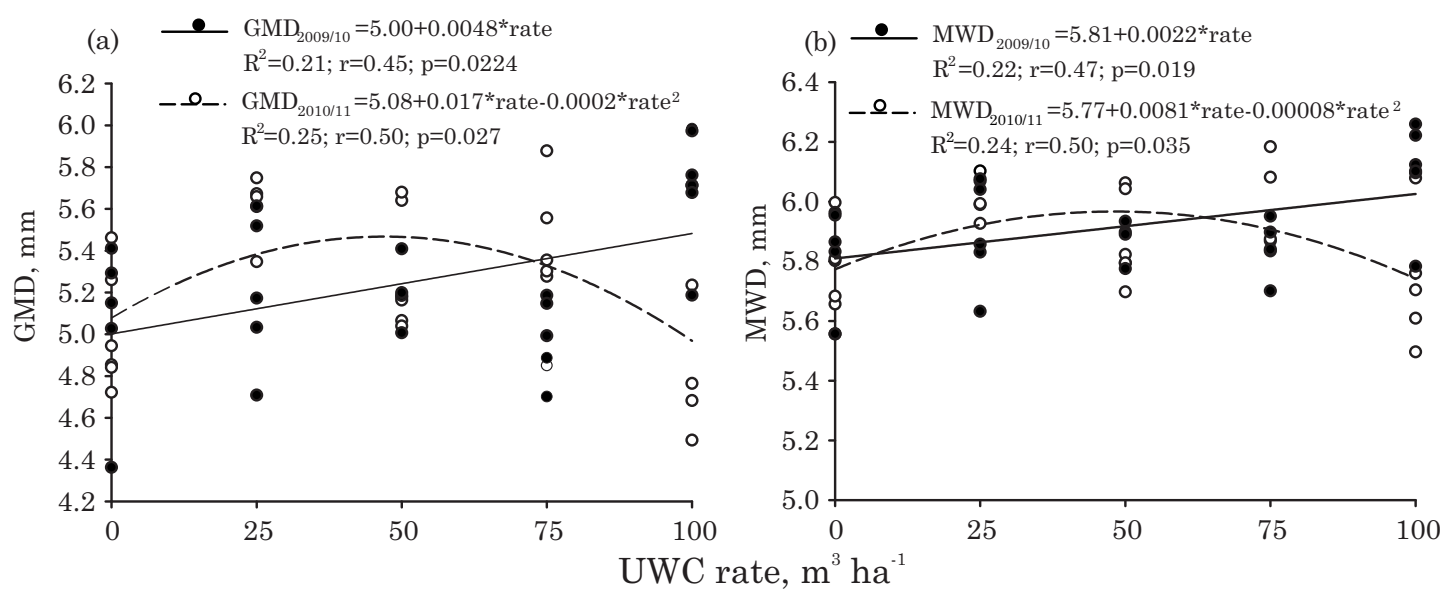

Figure 1. Geometric (GMD) and mean weight diameter (MWD) of the Rhodic Hapludox under different rates of urban waste compost (UWC).

who evaluated the use of alkaline residue from the pulp and paper industry to correct soil acidity. The authors reported increased aggregation with 2.6 $\mathrm{Mg} \mathrm{ha}^{-1}$ and dispersing effect of the chemical elements when higher rates were applied (10.5 $\left.\mathrm{Mg} \mathrm{ha}^{-1}\right)$. Arruda et al. (2010) observed that the aggregate stability in an Oxisol was higher in the control treatment $(\mathrm{GMD}=6.1 \mathrm{~mm})$ and decreased with the application of 50 and $100 \mathrm{~m}^{3} \mathrm{ha}^{-1}$ of pig slurry $(\mathrm{GMD}=5.7 \mathrm{~mm})$. Also, Oades (1984) observed that organic acids can exert direct dispersing effects or aggregate complexation by cations such as $\mathrm{Al}^{3+}$.

The GMD values were about $0.6 \mathrm{~mm}$ lower than those of MWD, indicating that the average aggregate size depends on the method employed for calculating the average values of the aggregates. According to Dortzbach et al. (2008), this overestimation of MWD compared to GMD can occur when sampling is performed in the topsoil $(0.0-0.10 \mathrm{~m})$, as done in this study, where the percentage of large aggregates is higher, due to the increased activity of plants, microorganisms and cementing agents, which is strongly influenced by the presence of organic matter. Kemper \& Chepil (1965) stated that the GMD is an estimate of the size of the class with the highest occurrence of aggregates, whereas MWD is greater with higher percentage of large aggregates retained on sieves with larger pores. Therefore, GMD can be considered a more precise parameter to represent soil aggregation (Dortzbach et al., 2008).

The results indicated that the UWC rates applied and periods of evaluation induced variations in aggregate retention in the different size classes (Figure 2 ). In both years, over $80 \%$ of the aggregates were retained in the sieve class $8.0-4.76 \mathrm{~mm}$. In the 2009/ 10 growing season, results were similar for both GMD and MWD (Figure 1), with a linear increase in the quantity of aggregates retained in the sieve class 8.00$4.76 \mathrm{~mm}$, indicating that aggregate stability increases with UWC application on the soil. This may be related to greater root growth and the contribution of organic matter, as also reported by Matos et al. (2008).

In the 2010/11 growing season, the data showed a quadratic behavior of the relation between the different UWC rates and the percentage of aggregates retained in sieve class $8.00-4.76 \mathrm{~mm}$. As similarly observed for GMD and MWD (Figure 1), the point of maximum technical efficiency (91\%) of aggregates retained on the 8.0-4.76 mm sieve was observed from $49 \mathrm{~m}^{3} \mathrm{ha}^{-1}$ of UWC and above this rate, the percentage of retained aggregates decreased. Santi et al. (2012) evaluated the evolution of soil aggregation in a no-tillage area with different production potentials and managed under precision agriculture, observed that the values of water-stable aggregates of the class $8.00-4.76 \mathrm{~mm}$ and GMD can be used as indicators of soil physical quality, aiming at separating areas with distinct production potential.

A reduction of the amounts of water-stable aggregates retained on the sieve of 8.00-4.76 $\mathrm{mm}$ for UWC rates above $50 \mathrm{~m}^{3} \mathrm{ha}^{-1}$ (second year of assessment) was also observed with application of high rates of other organic sources, such as alkaline residues from the pulp and paper industry (Medeiros et al., 2009), pig slurry (Arruda et al., 2010), vinasse from sugarcane (Passarin et al., 2007), and turkey litter (Costa et al., 2008; Pinto et al,. 2012). The comparison of the effects of different organic waste sources on soil aggregation may be valid, mainly because the interactions as well as the mechanisms of flocculation and/or dispersion of soil particles are similar. However, it is worth mentioning that these mechanisms are highly dependent on the amount of dispersing or flocculating elements found in the organic waste.

According to Passos et al. (2007), the reduction of macroaggregation as a function of fertilization using organic sources may be favorable in view of chemistry, because microaggregates, besides being responsible for most of the stock of organic matter, represent an 


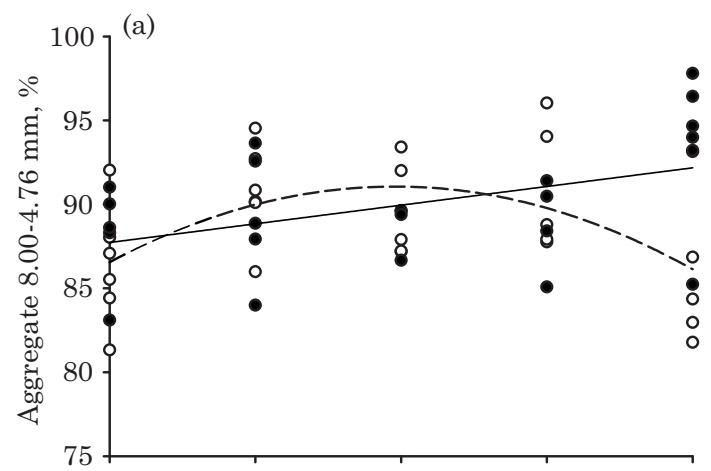

$$
\begin{aligned}
& \text { - } \text { Agre }_{2009 / 10}=87.72+0.0445 * \text { rate } \\
& \mathrm{R}^{2}=0.20 ; \mathrm{r}=0.45 ; \mathrm{p}=0.0287 \\
& \text { 은. } \text { Agre }_{2010 / 11}=86.55+0.1842 * \text { rate- } 0.0019 * \mathrm{rate}^{2} \\
& \mathrm{R}^{2}=0.25 ; \mathrm{r}=0.50 ; \mathrm{p}=0.0294
\end{aligned}
$$
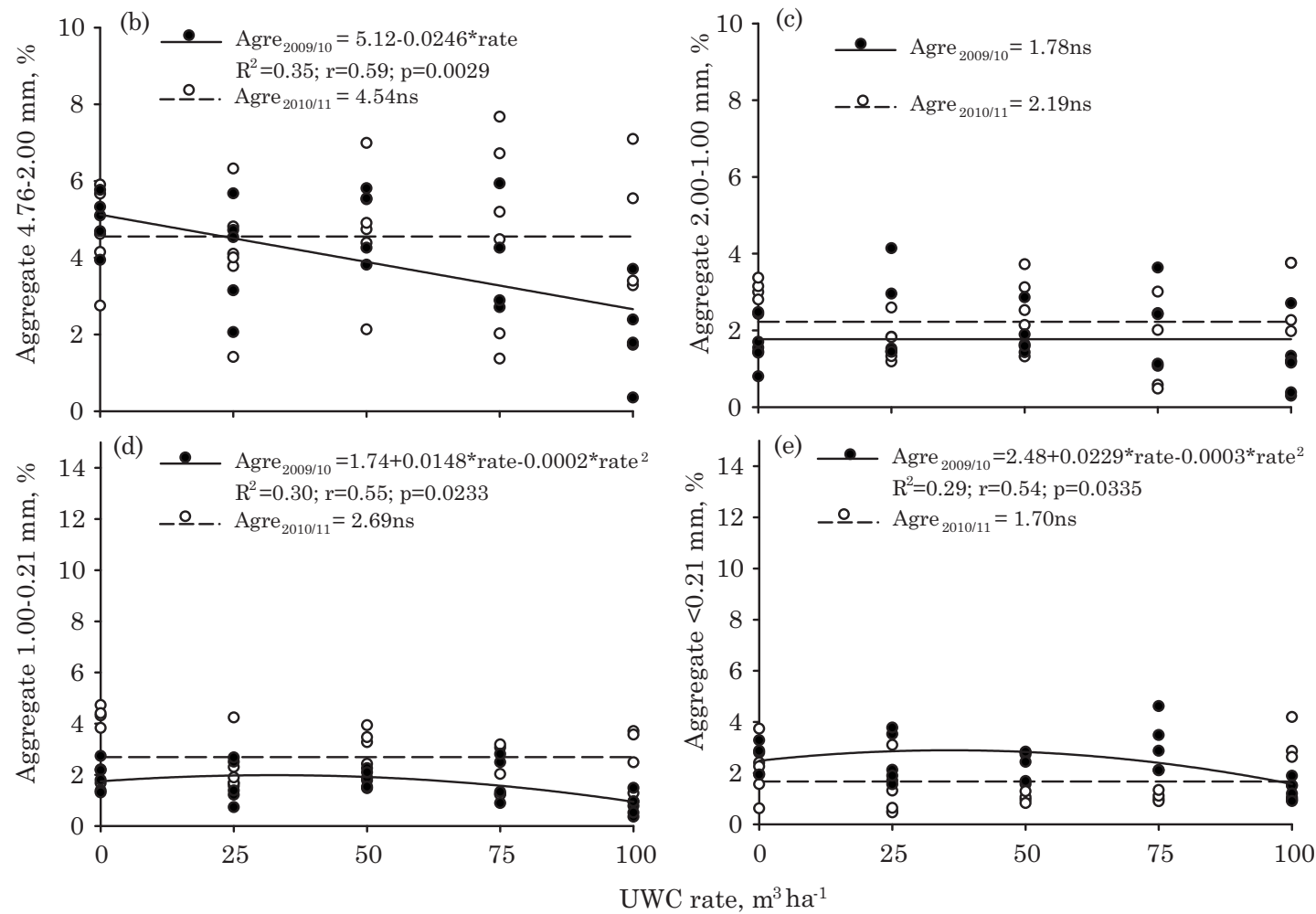

Figure 2. Aggregate distribution in classes: a) 8.00-4.76 mm; b) 4.76-2.00 mm; c) 2.00-1.00 mm; d) 1.00-0.21 mm; e) $<0.21 \mathrm{~mm}$, of a Rhodic Hapludox due to application of urban waste compost (UWC). ns not significant by the F-test $(\mathbf{p}<0.05)$.

important site of $\mathrm{N}$ mineralization. However, from the point of view of soil physics, the reduction in the size of water-stable aggregates indicates that the soil is more susceptible to disaggregation and dispersion of clay fraction, resulting in greater susceptibility to erosion (Azevedo \& Bonumá, 2004).

Soil organic carbon (SOC) and total nitrogen (TN) increased linearly with increasing UWC rates over the two years (Figure 3), although this effect was more significant in the second year. When $100 \mathrm{~m}^{3} \mathrm{ha}^{-1}$ of UWC was applied for two consecutive years, SOC and TN increased significantly, compared to mineral fertilization (Table 5). These results are in agreement with those of Scherer et al. (2007), who evaluated the effect of annual pig slurry application on an Oxisol for three consecutive years. The authors observed an upward trend in organic matter content in the surface layer $(0.0-0.10 \mathrm{~m})$, which they explained by the absence of incorporation of manure and plant residues into the soil, making the mineralization of organic compounds slower and gradual in the top few centimeters of the surface layer.

Thus, over the years, the accumulation of organic material because of UWC application can increase the organic matter content and, indirectly, enhance the aggregate stability of a SOC. Matos et al. (2008) observed increases in SOC contents over time with the use of organic fertilizer (common bean and soybean straw + cattle manure). However, Pinto et al. (2012) found that the soil carbon stock of an Oxisol varied in a quadratic manner in relation to the increased application of waste from turkey litter. Moreover, Arruda et al. (2010) observed that SOC contents were not influenced by the addition of pig 
slurry. These authors attributed the absence of increase in SOC contents to greater microbial activity resulting in greater intensity in the mineralization of soil organic matter.

Soil organic carbon and NT in the control treatment (without UWC application) were higher in the 2010/11 than the 2009/10 growing season (Figure 3). This can be attributed to greater addition of organic residue from maize (approximately 10 $\mathrm{Mg} \mathrm{ha}^{-1}$ shoot and root dry mass) compared to sunflower (approximately $3 \mathrm{Mg} \mathrm{ha}^{-1}$ shoot and root dry mass). Occasionally, this increase in the amount of particulate matter present in the soil surface may contribute to future increase in SOC and NT, and consequently increase soil organic matter (Conte et al., 2009). Therefore, the increase in SOC and NT from 2009/10 to 2010/11, aside from the contribution due to the addition of UWC, could be related to maize cultivated in the 2010/11 season.

A positive linear relationship between NT and UWC rates, as observed in this study, agrees with the results reported by Pinto et al. (2012). However, these authors found that different levels of turkey litter waste did not affect soil aggregation. In this study, the response of carbon and nitrogen contents to different UWC rates was similar, since, regardless of the treatment, the $\mathrm{C}: \mathrm{N}$ ratio $(11: 1)$ was constant (Table 5).

Increased levels of SOC from UWC applications induced a linear increase in GMD and MWD (Figure 4) in both growing seasons (2009/10 and 2010/11).
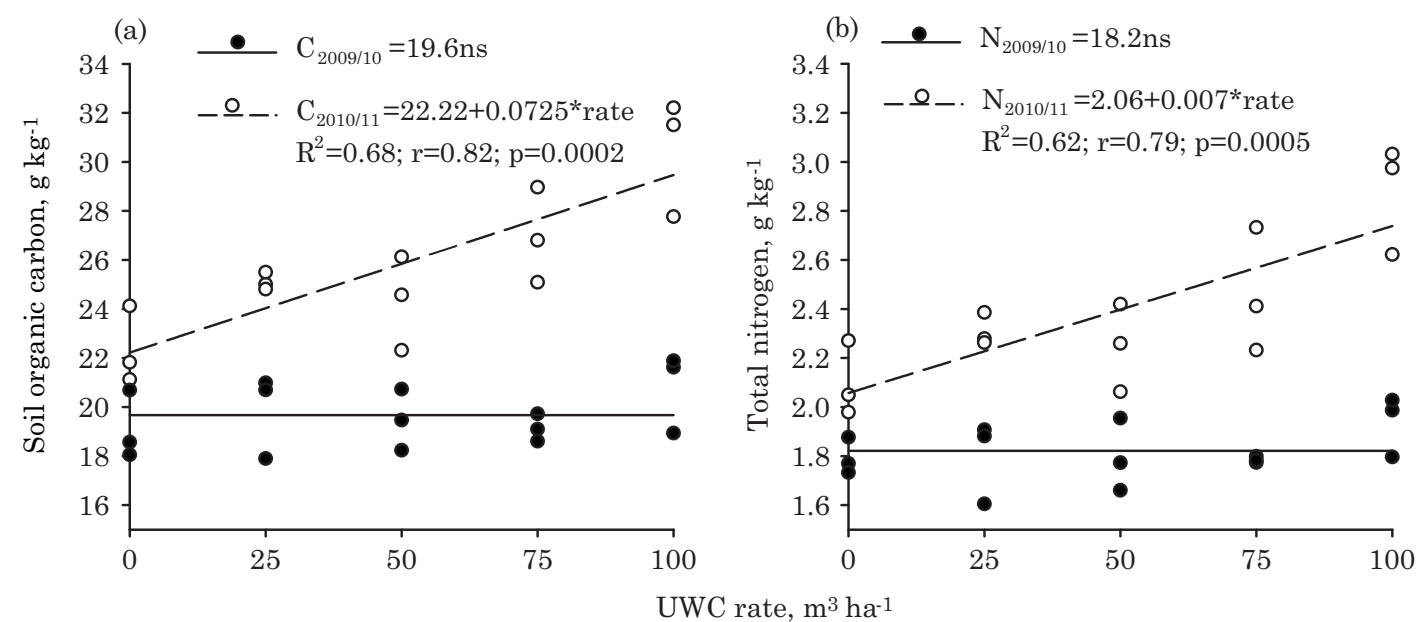

Figure 3. (a) Soil organic carbon and (b) total nitrogen as a function of rates of urban waste compost (UWC) applied to a Rhodic Hapludox during the 2009/10 and 2010/11 growing seasons.
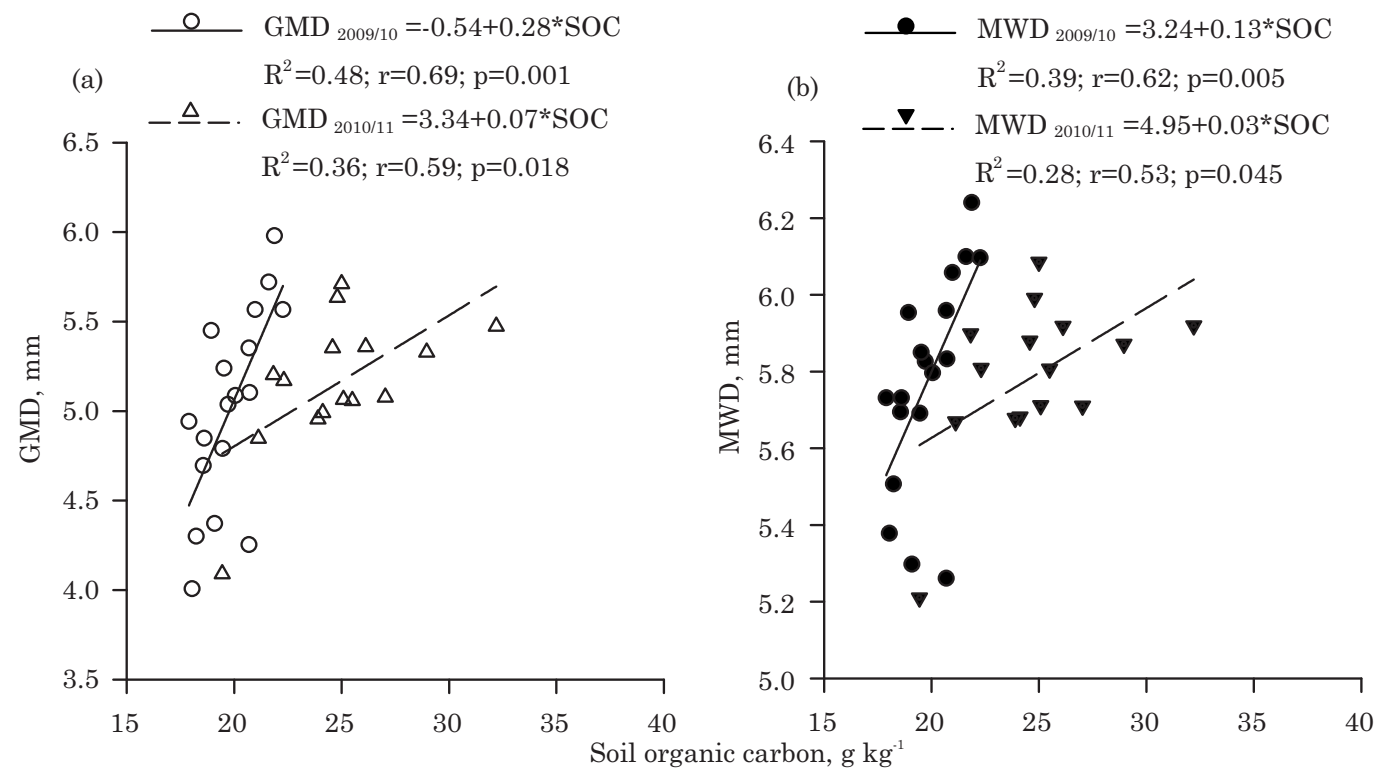

Figure 4. (a) Geometric mean diameter (GMD) and (b) mean weight diameter (MWD) relationship with organic carbon content of soil aggregates of a Rhodic Hapludox. 
These results agree with those of Matos et al. (2008), who observed an increase in carbon stocks and soil aggregate stability from the application of organic fertilizer. Rozane et al. (2010) evaluating the effect of management systems on aggregate stability, observed that GMD and MWD were higher in the 0.0-0.10 m layer, related to the increase in SOC content.

Vezzani \& Mielniczuk (2009) stated that when organic compounds are added to the system, they interact with other components and promote aggregate formation, following a sequence of events over time, which results in the formation of structures according to a hierarchy of size and complexity, characterizing the different levels of the system order. This favors the improvement of the soil structural quality (Vezzani \& Mielniczuk, 2009). Therefore, the importance of using organic sources in partial or total substitution of chemical fertilization is highlighted, to improve soil properties (chemical, physical and biological) and the agricultural production, and to promote an environmentally adequate destination for organic wastes resulting from human action.

\section{CONCLUSIONS}

1. Two years of applications at urban waste compost rates of up to $75 \mathrm{~m}^{3} \mathrm{ha}^{-1}$, produced in the northwestern region of Rio Grande do Sul, increased the stability of water-stable aggregates of a Rhodic Hapludox under notillage maize, oat and sunflower compared to mineral fertilization under the regional climatic conditions.

2. Urban waste compost applied to a Rhodic Hapludox under no-tillage in the northwestern region of Rio Grande do Sul, increased soil organic carbon and total nitrogen proportionally to the rates and in a cumulative manner over the two years.

\section{ACKNOWLEDGEMENTS}

We thank the Brazilian Council for Scientific and Technological Development $(\mathrm{CNPq})$ for the financial support; and the Intermunicipal Consortium for Solid Waste Management (CIGRES) for providing the urban waste compost analyzed in this study.

\section{LITERATURE CITED}

ABREU JUNIOR, C.H.; BOARETTO, A.E.; MURAOKA, T. \& KIEHL, J.C. Uso agrícola de resíduos orgânicos potencialmente poluentes: Propriedades químicas do solo e produção vegetal. In: TORRADO-VIDAL, P.; ALLEONI, L.R.F.; COOPER, M. \& SILVA, A.P., eds. Tópicos em ciência do solo. Viçosa, MG, Sociedade Brasileira de Ciência do Solo, 2005. v.4, p.391-470.
ARRUDA, C.A.O.; ALVES, M.V.; MAFRA, A.L.; CASSOL, P.C.; ALBUQUERQUE, J.A. \& SANTOS, J.C.P. Aplicação de dejeto suíno e estrutura de um Latossolo Vermelho sob semeadura direta. Ci. Agrotec., 34:804-809, 2010.

AZEVEDO, A.C. \& BONUMÁ, A.S. Partículas coloidais, dispersão e agregação em Latossolos. Ci. Rural, 34:609$617,2004$.

BONINI, C.S.B. \& ALVES, M.C. Estabilidade de agregados de um Latossolo Vermelho degradado em recuperação com adubos verdes, calcário e gesso. R. Bras. Ci. Solo, 35:1263$1270,2011$.

CALDERAN, T.B. Consórcio público intermunicipal de gerenciamento de resíduos sólidos domésticos: Um estudo de caso. Lajeado, Centro Universitário Univates, 2013. 223p. (Dissertação de Mestrado)

CALDERAN, T.B.; MAZZARINO, J.M. \& KONRAD, O. Consórcios intermunicipais para a gestão de resíduos sólidos domésticos e como elemento de desenvolvimento regional sustentável. R. Direito Amb., 17:317-336, 2012.

CITAK, S. \& SONMEZ, S. Effects of chemical fertilizer and different organic manure application on soil $\mathrm{pH}, \mathrm{EC}$ and organic matter content. J. Food Agric. Environ., 9:739$741,2011$.

CONCEIÇÃO, P.C.; DIECKOW, J. \& BAYER, C. Combined role of no-tillage and cropping systems in soil carbon stocks and stabilization. Soil Till. Res., 129:40-47, 2013.

COSTA, A.M.; RIBEIRO, B.T.; SILVA, A.A. \& BORGES, E.N. Estabilidade de agregados de um Latossolo Vermelho tratado com cama de peru. Ci. Agrotec, 32:73-79, 2008.

COMISSÃO DE QUÍMICA E FERTILIDADE DO SOLO . CQFS/RS-SC. Manual de adubação e calagem para os estados do Rio Grande do Sul e Santa Catarina. Porto Alegre, Sociedade Brasileira de Ciência do Solo - Núcleo Regional Sul, 2004. 400p.

CONTE, O.; LEVIEN, R.; TREIN, C.R.; DEBIASI, H. \& MAZURANA, M. Rendimento do milho em diferentes condições físicas de solo e quantidade de resíduo na ausência ou na presença de irrigação. Ci. Rural, 39:10691076, 2009

DORTZBACH, D.; LÉIS, C. M.; COUTO, R.R.; BEBER, C.L. \& COMIN, J.J. Estabilidade de agregados do solo submetido a diferentes aplicações de dejetos suínos e ureia em um Argissolo. Florianópolis, EPAGRI, 2008. Available at: $<$ http://intranetdoc.epagri.sc.gov. br/producao_ tecnico_cientifica/DOC_3081.pdf>. Accessed: 28 jun. 2013.

KEMPER, W.D. \& CHEPIL, W.S. Size distribution of aggregates. In: BLACK, C.A., ed. Methods of soil analysis. Madison, American Society of Agronomy, 1965. p.499-509.

KRAY, C.H.; TEDESCO, M.J.; BISSANI, C.A.; BORTOLON, L.; ANDREAZZA, R.; GIANELLO, C. Avaliação da aplicação de composto de lixo urbano e lodo de esgoto em dois solos diferentes. Pesq. Agropec. Gaúcha, 17:119-125, 2011.

KROB, A.D.; MORAES, S.P.; SELBACH, P.A.; BENTO, F.M. \& CAMARGO, F.A.O. Propriedades químicas de um Argissolo tratado sucessivamente com composto de lixo urbano. Ci. Rural, 41:433-439, 2011. 
LIMA, R.L.S.; OLIVEIRA, S.M. \& BORGES, E.N. Atributos químicos de substrato de composto de lixo orgânico. R. Bras. Eng. Agríc. Amb., 15:185-192, 2011.

MALUF, J.R.T. Nova classificação climática do Estado do Rio Grande do Sul. R. Bras. Agrometeorol., 8:141-150, 2000.

MANTOVANI, J.R.; FERREIRA, M.E.; CRUZ, M.C.P.; BARBOSA, J.C. \& FREIRIA, A.C. Mineralização de carbono e de nitrogênio provenientes de composto de lixo urbano em Argissolo. R. Bras. Ci. Solo, 30:677-684, 2006.

MATOS, E.S.; MENDONÇA, E.S.; LEITE, L.F.C. \& GALVÃO, J.C.C. Estabilidade de agregados e distribuição de carbono e nutrientes em Argissolo sob adubação orgânica e mineral. Pesq. Agropec. Bras., 43:1221-1230, 2008.

MEDEIROS, J.C.; ALBUQUERQUE, J.A.; MAFRA, A.L.; BATISTELLA, F. \& GRAH, J. Calagem superficial com resíduo alcalino da indústria de papel e celulose em um solo altamente tamponado. R. Bras. Ci. Solo, 33:1657$1665,2009$.

MELO, A.V.; GALVÃO, J.C.C.; SANTOS, M.M.; COIMBRA, R.R.; SILVA, R.R. \& REIS, W.F. Extração de nutrientes e produção de biomassa de aveia-preta cultivada em solo submetido a dezoito anos de adubação orgânica e mineral. Semina: Ci. Agron., 32:411-420, 2011.

MORAES, M.T.; SILVA, V.R. \& ARNUTI, F. Resíduos líquidos de efluentes de agroindústria de carnes na produtividade do girassol. Enciclop. Biosfera, 8:843-853, 2012.

OADES, J.M. Soil organic matter and structural stability: Mechanisms and implications for management. Plant Soil, 76:319-337, 1984.

PASSARIN, A.L.; RODRIGUEIRO, E.L.; ROBAINA, C.R.P. \& MEDINA, C.C. Caracterização de agregados em um Latossolo Vermelho distroférrico típico submetido a diferentes doses de vinhaça. R. Bras. Ci. Solo, 31:12551260, 2007.

PASSOS, R.R.; RUIZ, H.A.; CANTARUTTI, R.B. \& MENDONÇA, E.S. Carbono orgânico e nitrogênio em agregados de um Latossolo Vermelho distrófico sob duas coberturas vegetais. R. Bras. Ci. Solo, 31:1109-1118, 2007.

PINTO, F.A.; SANTOS, F.L.; TERRA, F.D.; RIBEIRO, D.O.; SOUSA, R.R.J.; SOUZA, E.D.; CARNEIRO, M.A.C. \& PULINO, H.B. Atributos de solo sob pastejo rotacionado em função da aplicação de cama de peru. Pesq. Agropec. Trop., 42:254-262, 2012.

REICHERT, J.M.; NORTON, L.D.; FAVARETTO, N.; HUANG, C. \& BLUME, E. Settling velocity, aggregate stability, and interrill erodibility of soils varying in clay mineralogy. Soil Sci. Soc. Am. J., 73:1369-1377, 2009.
RHEINHEIMER, D.S.; CAMPOS, B-H.C.; GIACOMINI, S.J.; CONCEIÇÃO, P.C. \& BORTOLUZZI, E.C. Comparação de métodos de determinação de carbono orgânico total no solo. R. Bras. Ci. Solo, 32:435-440, 2008.

ROZANE, D.E.; CENTURION, J.F.; ROMUALDO, L.A.; TANIGUCHI, C.A.K.; TRABUCO, M. \& ALVES, A.U. Estoque de carbono e estabilidade de agregados de um Latossolo Vermelho Distrófico, sob diferentes manejos. Biosci. J., 26:24-32, 2010.

SAMPAIO, R.A.; RAMOS, S.J.; SILVA, L.G.; COSTA, C.A. \& FERNANDES, L.A. Produção e teor de metais pesados em alface adubada com composto de lixo urbano. R. Bras. Ci. Agrár., 5:298-302, 2010.

SAMPAIO, T.F.; GUIVARA, L.; FERNANDES, L.A.; COSTA, C.A. \& GUILHERME, D.O. Lodo de esgoto na recuperação de áreas degradadas: Efeito nas características físicas do solo. R. Bras. Ci. Solo, 36:1637-1645, 2012.

SANTI, A.L.; CHERUBIN, M.R.; EITELWEIN, M.T.; SIMON, D.H. \& PIAS, O.H.C. Evolução da agregação do solo em áreas com diferentes potenciais produtivos manejadas com agricultura de precisão. Enciclop. Biosfera, 8:2132$2141,2012$.

SANTOS, H.G.; JACOMINE, P.K.T.; ANJOS, L.H.C.; OLIVEIRA, V.A.; LUBRERAS, J.F.; COELHO, M.R.; ALMEIDA, J.A.; CUNHA, T.J.F. \& OLIVEIRA, J.B., eds. Sistema brasileiro de classificação de solos. 3.ed. Brasília, Embrapa, 2013. 353p.

SCHERER, E.E.; BALDISSERA, I.T. \& NESI, C.N. Propriedades químicas de um Latossolo Vermelho sob plantio direto e adubação com esterco de suínos. R. Bras. Ci. Solo, 31:123-131, 2007.

SIX, J.; PAUSTIAN, K.; ELLIOTT, E.T. \& COMBRINK, C. A history of research on the link between (micro) aggregates, soil biota, and soil organic matter dynamics. Soil Till. Res., 79:7-31, 2004.

SOIL SURVEY STAFF. Keys to soil taxonomy. 11.ed. Washington, DC, USDA/NRCS, 2010.

STROJAKI, T.V.; SILVA, V.R.; SOMAVILLA, A.; DA ROS, C.O. \& MORAES, M.T. Atributos químicos do solo e produtividade de girassol e milho em função da aplicação de composto de lixo urbano. Pesq. Agropec. Trop., 43:278$285,2013$.

TISDALL, J.M. \& OADES, J.M. Organic matter and water stable aggregates in soils. J. Soil Sci., 33:141-163, 1982.

VEZZANI, F.M. \& MIELNICZUK, J. Uma visão sobre qualidade do solo. R. Bras. Ci. Solo, 33:743-755, 2009. 